\title{
A Framework for Thinking about Enterprise Formalization Policies in Developing Countries
}

\author{
Thomas Kenyon \\ tkenyon@worldbank.org
}

\begin{abstract}
What policies encourage firms to become 'formal'? The standard approach emphasizes reducing the costs of compliance with government regulation. This is unlikely to be sufficient. Instead we need to understand compliance as a function not only of firm-level costs and benefits but also in terms of the interaction between the firm and its competitors and between the firm and the state. This paper emphasizes the coordination and credibility issues involved in promoting formalization and discusses possible institutional solutions, among them business associations that make the benefits of membership dependent on compliance, information sharing arrangements among government agencies and improvements in the quality of public management.
\end{abstract}

World Bank Policy Research Working Paper 4235, May 2007

The Policy Research Working Paper Series disseminates the findings of work in progress to encourage the exchange of ideas about development issues. An objective of the series is to get the findings out quickly, even if the presentations are less than fully polished. The papers carry the names of the authors and should be cited accordingly. The findings, interpretations, and conclusions expressed in this paper are entirely those of the authors. They do not necessarily represent the view of the World Bank, its Executive Directors, or the countries they represent. Policy Research Working Papers are available online at http://econ.worldbank.org. 


\section{Formalization: Concepts and Questions}

How do firms become 'formal'? What, if anything, can or should policy-makers do to encourage them? These are important questions. The best estimates we have suggest that over 30 percent of output and 70 percent of workers in developing countries are to some degree outside the scope of government regulation. Most people also agree that the proportion is rising over time. Where there is less agreement is over what to do about it. Nobody would argue that the state should turn a blind eye to criminal activity. But there is debate over whether it makes sense to formalize other forms of extra-regulatory activity - those that would be legal if not conducted outside the state's purview. Some have argued that informality is a rational response to inefficient regulation and that informal firms in developing countries should be regarded as analogous to the voluntary small enterprise sector in developed economies. Others have emphasized the externalities associated with regulatory evasion and the possible untoward effects of informality on growth and productivity.

This paper is concerned less with the causes and consequences of informality than with how the process of formalization occurs in practice. It takes as its starting point the assumption that where the potential for a voluntary accommodation between private enterprise and the state exists, it should be encouraged. The questions it addresses are why such accommodation might be difficult to achieve and how best to bring it about. Its objective is to provide a framework for thinking about the process of formalization that goes beyond the customary emphasis on regulatory simplification and addresses the collective action problems involved in building a culture of compliance between entrepreneurs and states in developing countries. Experience tells us self-interest alone is not always enough to ensure cooperation. At root, the task is one of creating a social contract between entrepreneurs and state. This does not happen overnight, but neither is it immutable. The purpose of paper is to delineate some of the factors that might make it possible and to throw out some conjectures for further empirical investigation.

\section{What do 'formal' and 'formalization' mean?}

In its original use, 'informal' activities were distinguished from 'formal' ones by their degree of rationalization, or embodiment of impersonal principles of social organization (Hart, 2005, 7). Given the identification of organizational rationality with the 'modern' state, the term has come to apply to those economic activities not subject to its regulation and control. This identification of formal rationality with states is potentially misleading, given the highly personalized characteristics of states in some parts of the world and the bureaucratic nature of some non-state forms of social organization. Nonetheless the 'legal' definition provides an adequate starting point. It is also helpful because it points to informality as a form of state failure. This can take several forms, according to whether the regulation in question concerns labor standards, taxation, product standards, land titles or some other form of government control. It is important to recognize the heterogeneity of the 'informal sector', encompassing as it does almost all sorts of activities, from the self-employed, to small businesses employing a handful of workers to, 
in some developing countries, quite large enterprises with several hundred employees. Some firms may be registered with one set of authorities but not another, for instance, or be registered but under-declare sales or workers for tax purposes.

'Formalization' refers to the process whereby previously non-compliant enterprises become integrated into these formal or state-sanctioned institutions, such as property registries and tax-rolls. We know relatively little about how this occurs in practice. Public policy may have a role to play, but the process need not necessarily take place under state sponsorship. The experience of some developed countries, Italy in particular, suggests that inducing regulatory compliance requires a combination of self-interest on the part of entrepreneurs, government intervention and ongoing self-monitoring (Locke and Criscuolo, 2006). The particular mix of public intervention and private initiative is also likely to vary from country to country and by type of enterprise. Since our concern is to encourage the growth of markets for products, finance and skills, most of the examples in this paper are drawn from cases of tax and product market formalization. But the mechanisms that promote compliance in these areas are similar to those for other forms of upgrading.

In thinking about formalization, we should acknowledge that formal or state-sanctioned institutions are more likely to succeed when they build on existing informal arrangements. The term 'accommodation' implies compromise on both sides. There must a commitment to compliance on the part of entrepreneurs. But 'bureaucratic institutions [also] need to be more flexible in their treatment of informal practices, so that more people can take shelter under the rule of law' (Hart, 2006, 13). This can involve adapting orthodox institutions for unorthodox ends - as in Ghana, where the road transport workers' union (GPRTU) has collected taxes on behalf of the state since the late 1980s and has the authority to enforce safety standards among its members (Joshi and Ayee, 2002); or Kenya and Tanzania where commodity marketing boards have performed a similar revenue-raising function. ${ }^{1}$

\section{When is formalization appropriate?}

We begin from the assumption that in so far as there is scope for a voluntary accommodation between informal enterprises and the state in developing countries, it should be encouraged. How large is the potential for such a bargain? The short answer is that we have no comprehensive data. But an IFC survey of Sierra Leone, for example, found that 80 percent of informal entrepreneurs would consider formalizing over the coming year. Another study of informal firms in South Africa found that only 24 percent thought their 'present level of compliance was sufficient, or saw no disadvantage in informal status' (SBP, 2005, 14). No doubt some informal enterprises would disappear if forced to comply with government regulation and it may well be that from some points of view integration into state-sponsored institutions does not make sense. But the potential for voluntary formalization would also appear to be large.

\footnotetext{
${ }^{1}$ Interview with Vandana Chandra, Senior Economist, Economic Policy and Debt Unit, Poverty Reduction Economic Management Network, World Bank.
} 
For whom does formalization make most sense? We are accustomed to thinking of the formalization decision in terms of costs and benefits to the firm. The former include registration and licensing fees and the ongoing costs of compliance with health and safety, social security and other labor regulations. Many informal enterprises evade taxation, though some are subject to inappropriate and sometimes arbitrary taxes and fees that cancel out the advantage of being outside the formal tax net. The benefits of formality to the firm are usually understood as including access to regulated markets for products, finance and training and to public institutions such as the courts and police. There is also some evidence that informal firms are more liable to extortion by government officials and more prone to suffer from crime. But these are not the only considerations. Informality carries social as well as private costs. A strong argument for formalization is that regulatory and tax evasion can be actively harmful, not only to workers and consumers but also to the formal firms that compete with them. Another is that largescale modern economic development depends on states and states cannot exist without a revenue base. This depends on their knowing the scope of economic activity within their borders, even if they refrain from taxing all of it.

The table below breaks the informal 'sector' out into two types of participants (workers and enterprises) and two sets of motivations or explanations for remaining informal (evasion/competition vs. exclusion/irrelevance). It also adds a brief summary of the policy implications, which I elaborate on in more detail below. The rest of the paper is concerned with the lower two quadrants: enterprises that are wholly or partially unregulated - either because they are using evasion as a means of competitive advantage or because they see few benefits in belonging to the system. While the former is probably of higher priority, in the long run policy-makers should also consider taking steps to make formalization more attractive to all firms.

Key distinctions: Workers vs. Enterprises \& Evasion vs. Exclusion - Policy Implications

\begin{tabular}{|l|l|l|}
\hline Informal workers & Evasion/Competition & Exclusion/Irrelevance \\
\hline Informal enterprises & - & $\begin{array}{l}\text { Mixed priority: provision of } \\
\text { safety nets, enforcement of labor } \\
\text { standards for the vulnerable; } \\
\text { passive support for voluntary' } \\
\text { entrepreneurial sector' }\end{array}$ \\
$\begin{array}{l}\text { High priority: emphasis on } \\
\text { enforcement } \\
\text { sharing, tighter penalties, naming } \\
\text { and shaming etc.) }\end{array}$ & $\begin{array}{l}\text { Medium priority: emphasis on } \\
\text { provision of benefits \& security } \\
\text { (e.g. training, access } \\
\text { finance/product markets); link to } \\
\text { tublic sector reform gradual shift } \\
\text { to enforcement }\end{array}$ \\
\hline
\end{tabular}


High priority: The social benefits of formalization are arguably greatest when the persistence of informality as a means of competitive advantage threatens to undermine the implicit bargain between state and formal enterprises. A series of McKinsey studies in the late 1990s found strong evidence that non-compliant enterprises were using tax and regulatory evasion as a means of competing unfairly with more productive formal enterprises (Palmade, 2005). There is a common assumption that all forms of regulation require adjustment to meet the needs of informal enterprises. But 'focusing on the difficulties small and informal firms face in meeting the costs of ... standards distracts our attention from pursuing opportunities to rise to the occasion and meet these standards, rather than be exempt from them' (Tendler, 2002, 6). The most encouraging stories are those in which informal firms have overcome the obstacles to participation in formal markets - often under the threat of more stringent enforcement.

Low priority: Some have argued that informality is a natural state for very small enterprises and that the costs of exclusion only become apparent once the firm reaches a certain size. This is particularly relevant in many low income countries, where the predominant form of employment is self-employment. Examples include the very poor or seasonal workers who engage in income-generating activity as and when circumstances require (Citron, 2004, 114), or those engaged in subsistence agriculture. Some commentators have gone even further and argued that extra-legality is an appropriate and workable strategy; others have argued that what matters is improving the livelihoods of workers in the informal economy, not encouraging formalization (USAID, 2005, 22). Maloney makes a useful distinction between informal workers and those employed in micro-enterprises, whom he argues should be tolerated as akin to the voluntary small business sector in developed countries, and larger enterprises that are either wholly or partially outside the regulatory system (Maloney, 2006, 9).

\section{Explaining Formalization: Beyond 'Carrots' and 'Sticks'}

We take the 'carrot' and 'stick' approach as our starting point. It is commonly accepted that there are costs and benefits of participating in societal institutions. The remedy derived from this diagnosis is straightforward: to alter the calculus of costs and benefits by amending the legal regime to suit reality. This means simplifying business registration requirements; it may also involve creating appropriate legal categories for enterprises that do not fit into the existing framework. On the tax side, it may require a combination of simplified and more predictable tax regime and more effective enforcement (Engelschalk, 2005, 27). More generally, tackling regulatory evasion requires governments to pay more attention to detection and enforcement - on which they typically spend far less than their counterparts in developed countries. This analysis is largely uncontroversial. It is a commonplace that compliance depends on firms' perceiving that it is in their self-interest. And there is a large empirical literature, some of it based on survey evidence, that the more individuals and firms perceive that they are receiving quality public services, the more willing they are to pay taxes. ${ }^{2}$ But the required blend between 'carrots' and 'sticks' is likely to vary substantially from case to case. Among other things, we should expect it

\footnotetext{
${ }^{2}$ See Hanousek and Palda, 2004, for an overview and discussion of the situation in transition economies.
} 
to depend on the nature of relations between the state and informal private sector. Where firms are registered but not paying taxes, for instance, it may be appropriate to concentrate more on enforcement and information-sharing. Where enterprises are wholly outside the system, the inducements may need to be more positive, as we discuss in more detail below. First, though, why might such an arrangement be difficult to arrive at?

\section{Informality as a strategic problem}

Coordination: One reason is that, like many other social situations, the formalization decision is strategic - it depends on the decisions of others. It probably does not make sense for an entrepreneur to incur the costs of compliance with government regulation unless he or she can be sure that his or her competitors do the same. The underlying problem is a lack of coordination: Why pay taxes, register or comply with costly health and safety standards when nobody else does? Not only are you unlikely to receive any public services in return, you also place yourself at a severe competitive disadvantage. The result is that informal firms have little incentive to formalize and formal ones are deterred from investing and expanding - with potentially serious consequences for growth in output and productivity.

Credibility: But there is another dimension to the problem. Not only does individual compliance depend on other entrepreneurs' behavior; it also depends on the government upholding its side of the bargain. Once registered, it is harder for enterprises to evade predatory as well as legitimate interventions by the state. It is quite common for national governments to declare themselves in favor of 'promoting the informal sector' at the same time as municipal authorities harass informal entrepreneurs and destroy their equipment and premises. It is also common for officials to backtrack on a commitment as in Morocco, where the local government in Marrakech first guaranteed street vendors a reduced tax rate if they registered their businesses and then once they had done so charged them four times the promised amount and required them to pay back taxes for the past five years (Citron, 2004, 110). Persuading informal enterprises to formalize requires governments to commit credibly against this sort of behavior.

Information: Lastly, successful cooperation requires information about the benefits of participation. This may seem obvious but it is surprising how many government programs in developing countries fail to communicate with their intended beneficiaries. According to the IFC survey of informal firms in Sierra Leone, lack of information is the single most important deterrent to acquiring a business license - ahead of costs and inconvenience (FIAS, 2006, 40). A 2001 Tanzanian government tax simplification program failed because, crucially, the authorities did not inform entrepreneurs about the change (USAID, 2005, 31). And a study of the informal sector in Kenya concluded that 'only a tiny fraction of the jua kali [informal sector workers] know anything about the myriad schemes and projects designed to assist them’ (King, 1996, 191).

The relative prevalence of these obstacles to formalization is likely to vary according by economic environment and firm type, as the table below shows. Coordination is likely to be more of a problem when informal enterprises compete directly with formal ones or 
when semi-formal firms employ regulatory evasion as a source of competitive advantage. This may be a more prominent issue in middle-income countries such as Brazil, Russia and Turkey than it is in most of Africa. Meanwhile credibility and vulnerability to predation are likely to be more salient for smaller enterprises such as owner-operated businesses that are wholly outside the system. A preliminary canvassing of opinion among policy-makers suggests the threat of extortion is among the most important deterrents to formalization in African countries. And the problem is not limited to corruption among officials: in mining communities, for instance, registering a business immediately exposes an entrepreneur to theft and violence on the part of his or her peers.

Summary of Obstacles and Possible Solutions

\begin{tabular}{|l|l|l|l|}
\hline Problem & Typical Environment & Typical Firm & Solution \\
\hline Information & $\begin{array}{l}\text { Lower income countries } \\
\text { or regions (most of } \\
\text { Africa) }\end{array}$ & $\begin{array}{l}\text { Small enterprises, owner } \\
\text { operators }\end{array}$ & $\begin{array}{l}\text { Information campaigns, } \\
\text { mechanisms for public } \\
\text { private dialogue }\end{array}$ \\
\hline Coordination & $\begin{array}{l}\text { Middle income } \\
\text { countries or regions (e.g. } \\
\text { southern Brazil, eastern } \\
\text { Europe) }\end{array}$ & $\begin{array}{l}\text { Larger firms in } \\
\text { oligopolistic industries }\end{array}$ & $\begin{array}{l}\text { Business/other associations that make } \\
\text { benefits dependent on } \\
\text { compliance; greater } \\
\text { emphasis on } \\
\text { enforcement and } \\
\text { information sharing } \\
\text { within government }\end{array}$ \\
\hline Credibility \& trust & $\begin{array}{l}\text { Lower income countries } \\
\text { or regions (e.g. sub- } \\
\text { Saharan Africa) }\end{array}$ & $\begin{array}{l}\text { Small enterprises, owner } \\
\text { operators }\end{array}$ & $\begin{array}{l}\text { Link to public sector } \\
\text { reform, mechanisms for } \\
\text { confidence building - } \\
\text { explicit connection of } \\
\text { benefits, initial emphasis } \\
\text { on carrots }\end{array}$ \\
\hline
\end{tabular}

\section{Approaches to a Solution}

This description of the formalization decision as strategic interaction will be familiar to some readers. The players are formal firms, informal firms and government officials charged with implementing the rules (who are not necessarily the same people as make the rules). The preferable outcome is one in which both formal and informal firms comply with government regulations and in which government officials enforce the rules consistently and fairly. Unfortunately such a situation may be hard to achieve: the reason being that both informal enterprises and some government officials can gain by failing to cooperate. Informal enterprises benefit from evading regulations and taxes while their formal competitors comply. In the meantime government officials can profit from running a protection racket in which they threaten to disrupt or evict informal 
entrepreneurs and then relent on the payment of bribes or promise of some other form of support, such as votes. ${ }^{3}$ Overcoming these difficulties requires a careful approach. Unfortunately governments sometimes worsen the problem by adding to the tax and regulatory burden on formal firms to compensate for poor enforcement. This simply drives more firms underground. Moreover, policy-makers need to recognize that simply closing down informal firms will throw many unskilled and poorly paid employees out of work, most of them beyond the reach of social safety nets. What are needed are institutional mechanisms to communicate the benefits of formalization to firms and to make both the benefits of compliance and the costs of non-compliance credible.

Here it may be useful to think of the potential bargain between states and enterprises as analogous to that between private actors. The problem is similar: how to encourage the development of a hierarchical rules-based system of contracting. Most business in African countries is conducted on the basis of small networks of entrepreneurs from similar ethnic backgrounds. The key to these networks' functioning is trust among individuals, developed on the basis of repeated personal interaction. What these mechanisms have in common is that they reduce the transactions costs associated with doing business. But relations-based systems are necessarily restricted in scope. As one scholar has put it, 'difficulties in contracting make African markets look resemble the flea markets and garage sales of developed countries' (Frazer, 2005, 322). They thus have much more in common with what the anthropologist Clifford Geertz termed the 'bazaartype' than the hierarchically organized 'firm-type' economies characteristic of developed countries (Geertz, 1963). The distinction between relations-based and rules-based systems is not altogether clear-cut: all developed economies, even the United States, rely to some degree on informal and personalized networks. But the analogy is useful in that the same arrangements that promote this transition among private entrepreneurs might well apply to the process of formalization. The following section outlines some of these institutional mechanisms.

\section{Practical Elements of a Solution}

The social science literature contains a number of recommendations for solving these sorts of games. Among the most important are those that increase the benefits of cooperation, the costs of non-cooperation and the likelihood of detecting and sanctioning non-cooperative behavior. In what follows we focus on four such mechanisms: complementary government interventions that link the compliance decision to access to markets for finance and skills; private business associations that include formalizing firms and exclude non-compliant ones; coordination across government agencies to improve monitoring and enforcement; and measures that limit the scope for predatory behavior among government officials. Our focus is based on a preliminary review of the secondary literature on formalization and should not be taken as definitive.

\footnotetext{
${ }^{3}$ See Tendler (2002) for an entertaining description of this process.
} 


\section{Understanding and linking incentives}

For the most part the policy discourse has focused on changes to the legal environment in which informal firms operate. But measures to reduce the costs of entry are unlikely to be sufficient in the absence of positive incentives or 'carrots.' Common sense suggests that linking these changes to access to other resources, such as training, finance and the provision of physical infrastructure may be even more effective. But the benefits of formalization are generally quite specific to each particular activity. In mining communities, for example, small scale artisans don't usually require loans but they do require a reliable means of holding and transporting cash. Linking formalization to credit would make little sense but providing physical security might. ${ }^{4}$ Small scale service providers, such as suppliers of electricity, sanitation and water, need a stable legal environment because they have to make fixed investments that can be easily expropriated. Their overriding concern is not infrastructure or accreditation for their products, but the legitimacy that comes with regular status.

What, if any, is the relationship among the different aspects of formalization? Formalization is a multi-faceted process and the linkages vary from country to country. In some middle income countries, for example, it may be necessary to obtain an external audit in order to tap certain forms of finance, particularly equity market. This can deter firms that are hiding activities from the tax authorities from seeking a public listing (Kenyon, 2006). In lower income countries on the other hand, there is typically no interface or information sharing between credit or land titling registries and the tax authorities. Nor is there necessarily any connection between product market upgrading and some other aspects of formalization. Moroccan firms wishing to participate in government sponsored export programs need to be registered, certainly, but they would not necessarily need to undergo an audit and might well continue to under-declare sales and workers to the tax authorities. ${ }^{5}$ The evidence linking legal formalization to participation in markets is weak. A study of the impact of Peru's administrative law reform, for instance, found that its benefits had fallen well short of what was promised. ${ }^{6}$

Policymakers are often cautious about linking market access to registration or other bureaucratic requirements. They feel that markets should be open to all irrespective of status. And development practitioners, especially those in micro-finance, may be wary of linking formalization to access for finance for fear of undermining their business. There are also many cases in which such attempts have failed. In the late 1990s the South African government established education and training authorities to encourage SME development. The results have been inadequate for several reasons. Several authorities argued that they should prioritize the needs of formal firms since they were the ones paying the levies. Also many training providers regarded informal employees as untrainable because of their low literacy levels. Meanwhile, high levels of crime meant that

\footnotetext{
${ }^{4}$ Interview with Lucie Philips, President, IBI.

${ }^{5}$ Interview with Yasser Charafi, Projects Officer, IFC, Rabat, Morocco.

${ }^{6}$ Of the 512,000 families that received land titles between 1996 and 2000, for example, only about one percent had obtained a mortgage from a bank - which had been the original rationale for reform (Winterberg, 2005, 4).
} 
trainers were often unwilling to enter the areas in which potential trainees lived and worked (Lund and Skinner, 2005, 14). The one success story has been the baked goods sector, where the private suppliers of fixed capital equipment - i.e. ovens - provided both management training and credit together and had a strong financial incentive to ensure that their clients had adequate book-keeping and managerial skills. ${ }^{7}$

Nonetheless, it is worth thinking creatively about how to connect the costs and benefits of compliance - otherwise the incentive to regularize will disappear. There are various ways of doing it. In one case the government worked with commercial banks to persuade them to lower their cost of lending to enterprises that had committed to formalization. In another, a revenue authority allowed newly registered firms to charge higher VAT rates on their products than those they paid to their suppliers - effectively giving them a tax break. One approach might be to use pooled data on registered enterprises to make it easier for individuals to get access to, for example, health insurance or other services. And another possible intervention concerns physical infrastructure. The South African city of Johannesburg sought to formalize a cluster of enterprises in the garment sector into the formal economy by providing them with storage and office space in a specially designated 'fashion district.' It also gave them training and advice on marketing and business development. A controlled comparison later found that these interventions led not only to higher levels of output and employment, but also to product diversification and competitive upgrading (Rogerson, 2004, 422).

\section{Working through intermediaries}

The second lesson to emerge from our experience is that it is almost impossible to formalize unorganized informal sector enterprises. The best approach is to work through existing informal organizations. Ideally, governments should to identify 'amphibians' those individuals or associations with one foot in the informal and the other in the formal sector. The advantage of working through intermediaries is that they are generally more credible than governments, have closer knowledge of conditions on the ground and may be better placed to enforce bargains - providing selective benefits to those who choose to formalize. They are also well qualified to set common industry standards and identify and punish individuals who fail to meet them - a very important consideration in export clusters where even a single breach can undermine an industry's reputation. Finally informal sector organizations are also in a position to package information about their members and provide it to commercial banks or other service providers at a lower cost than if these outsiders did it for themselves.

The usual candidates for this intermediating function are business associations. Formal private sector associations can persuade entrepreneurs to formalize by making the benefits of membership contingent on regulatory compliance. The usefulness of business associations as instruments for economic development varies widely. In some cases, they have contributed to innovation and upgrading and, at times, to the formalization of

\footnotetext{
${ }^{7}$ Interview with Vandana Chandra, Senior Economist, Economic Policy and Debt Unit, Poverty Reduction Economic Management Network, World Bank.
} 
informal firms. In northern Italy, for example, producer groups offered technical assistance and administrative support to help businesses comply with tax rules. These services were also bundled with access to finance and product market certification, which meant that firms had a strong incentive to participate. Over time, this led to the generation of a 'compliance culture' and the graduation of large parts of Italian industry to the formal economy (Criscuolo, 2003). In Kenya the association of small tea-growers helped its members' compliance with national product standards by acquiring inputs, such as pesticides and fertilizers, in bulk and selling them at a discount to producers. ${ }^{8}$ Business associations in the Moroccan textile industry have played a similar role with respect to equipment and machinery. ${ }^{9}$ An association of handicrafts entrepreneurs in Madagascar has done the same with regard to tax compliance. ${ }^{10}$

Unfortunately, there are also many cases, particularly in Africa, in which business associations have acted in the manner predicted by public choice theorists - as lobbyists for a small number of influential firms. They tend to be dominated by large firms, often with close ties to political leaders - sometimes tripartite in form, though patronage-based. They also tend to concentrate on obtaining exemptions from existing policies, rather than participating in and influencing the development of new regulation. ${ }^{11}$ Sometimes governments have actively discouraged independent associations. In Kenya the Moi government first encouraged the formation of 'jua kali' or informal sector groups but then backtracked out of fear that they might emerge as a political force to threaten its position (Cohen, 2004).

Other potential partners include large formal firms - either individually or a part of an export processing zone (examples include Mittal Steel in Liberia and Mozal in Mozambique). But the role is not restricted to multinationals - domestic formal firms can be useful as well. In Senegal, locally-owned fish wholesalers selling to European markets have worked closely with informal suppliers to help them meet export standards - for instance, by providing them with ice so that their catch does not spoil en route to the processing plant and by issuing invoices on their behalf to keep track of production. The Senegalese experience shows the value of collaboration between formal and informal enterprises for securing market access via upgrading, but also illustrates its limits especially in industries that require careful resource management. Meanwhile in countries where private sector activities have been disrupted by conflict it can be advantageous to work with enterprises that were previously formal and which retain a 'memory' of what it is like to operate within a regulated system.

\section{Improving detection and sanctions}

In addition to linking compliance to market access and working through intermediaries, policymakers need to consider improving enforcement - the commonly referred to 'stick'.

\footnotetext{
${ }^{8}$ Interview with Yasuo Konishi, Managing Director, Global Development Solutions.

${ }^{9}$ Interview with Melani Cammett, Assistant Professor of Political Science, Brown University.

${ }^{10}$ Interview with Johane Rajaobelina. Operations Officer, International Finance Corporation, Madagascar.

${ }^{11}$ Interview with Adrienne Lebas, Assistant Professor of Political Science, Michigan State University.
} 
Thus a third hypothesis concerns the need for coordination among different government agencies. Enforcing compliance requires sharing information, particularly the tax authorities, business registries, social security administration and health and safety authorities. This is necessary because regulatory and tax evasion are harder to track than many other types of crime. Many OECD countries, for example, have introduced laws allowing the transfer of information among social security administrations, social services, the revenue authorities and health insurers. Some, such as the UK, have also allowed information sharing between these government agencies and private banks, utilities and educational establishments in an effort to eradicate social security fraud. In Ireland individuals not registered with the tax authorities are identified 'among other things by information on rent subsidy payments, purchases of property etc.' (OECD, 2004, 263).

Most developing countries lack such information-sharing mechanisms. In Morocco, for example, companies receive different identification numbers from the social security ministry, tax authorities and company registrar - making it impossible to trace their activities. This might appear to be a relatively simple technical issue, requiring the installation of an automated common system but in practice it is complicated by interagency rivalries and reluctance to cooperate. ${ }^{12}$ Several countries have experimented by introducing 'one-stop shops' for business registration that enable government agencies to draw on a single database and that might, theoretically at least, help them to identify evaders. A proposed scheme for Costa Rica, for instance, would provide common registration information to the tax authorities, social security institute, ministry of health and municipal chambers of commerce (World Bank, 2006, 15).

Since responsibility for implementation typically lies at the local level, effective policymaking also requires cooperation between across different levels of government. One of the emerging lessons from the South African experience is that 'the support and environmental needs of formal and informal enterprises are much the same, but governance in the business environment and in local government can operate in such a way as to create bottlenecks and constraints for the majority of smaller and poorer workers.' ${ }^{13}$ Meanwhile in Vietnam provincial authorities implemented a national Enterprise Law in such a way as to produce serious inconsistencies between its content and regulations on the ground (Kurz and Frode, 72, 2005) - with corresponding differences in the propensity of firms to register. A more positive example comes from Brazil, where the federal government established a National Antipiracy Council with members from seven government departments and private sector representatives. This has allowed more cooperation among the Federal Police, Internal Revenue and customs authorities and has led to several joint-policy operations. One result has been to cut smuggling along the Paraguayan border by 30 percent (Kenyon and Kapaz, 2005).

\section{Improving the quality of public management:}

\footnotetext{
${ }^{12}$ Interview with Najy Benhassine, Senior Private Sector Development Specialist, World Bank.

${ }^{13}$ Lund and Skinner, 2005, p. 3.
} 
A final set of solutions concerns the relationship between enterprise formalization and public sector management reform. Common sense suggests that formalization initiatives are more likely to succeed when accompanied by anti-corruption measures or at least by changes to business registration and other procedures that reduce opportunities for predation. It is often argued that simplifying regulatory procedures will in itself reduce corruption by limiting the opportunities for rent extraction. In the Ukraine, for instance, USAID claims that its BIZPRO reforms reduced corruption associated with business registration by 84 percent. ${ }^{14}$ Unfortunately we have been unable to find much other direct evidence of the link between anti-corruption programs and registration or tax compliance. But this is not to say that additional measures - like providing outside guarantees of intervention in the event of a breach of trust via an ombudsman - may not be worth experimenting with.

\section{Conclusion:}

This paper has sketched out some of the obstacles involved in constructing a bargain between informal or partially formal entrepreneurs and the state in developing countries, beyond the standard prescription of regulatory simplification, and hinted at possible institutional solutions. It emphasizes the strategic - as opposed to the individual level element of the entrepreneur's decision to regularize, focusing on the relationships between enterprise and public officials and among informal or formalizing enterprises. It also draws on the literature in political science to hint at some broad solutions, most of them involving intermediaries such as business or other informal sector associations. One of the points to emerge from our dialogue with policy-makers and representatives of informal sector associations in Africa is that is very difficult to formalize enterprises that are not already themselves organized in some fashion. My objective in doing so has been to convince the reader that the usual approach to enterprise formalization - regulatory simplification - may need to be complemented by other approaches and to point to the directions in which research and project work in this area might profitably be directed. Among the outstanding questions are: What is the appropriate balance between positive sanctions and enforcement and how might it change during the process of formalization? How might business associations and large firms be persuaded to cooperate with informal sector enterprises? And how should the policy approaches to informality discussed here be adapted to the differing needs of lower and middle-income countries or post-conflict environments and to the situation of firms in different economic sectors?

\section{Bibliography:}

Bigsten, Arne, Peter Kimuyu and Karl Lundvall, What to do with the Informal Sector? Development Policy Review, 2004, 22(6): 701-715.

\footnotetext{
${ }^{14} \mathrm{http} / / /$ ukraine.usaid.gov/accomp_econ.shtml
} 
Citron, Lisa Nicole. 2004. Continuity and Change: Anthropological Perspectives on the Informal Economy in Marrakech, Morocco, Unpublished $\mathrm{PhD}$ Thesis, Columbia University.

Cohen, Elin. 2004. Business Associations: a Strategy to Reduce Uncertainties in the Informal Business Sector in Kenya. Stanford Law School, PhD dissertation, unpublished.

Criscuolo, Alberto. 2003. 'High-Road Upgrading for Global Competition: the Role of Change Agents in Small Enterprise Development.' ILO-LED Working Paper. Washington, DC.

Dixit, Avinash, Lawlessness and Economics, Alternative Modes of Governance, Princeton, Princeton University Press, 2004.

Djankov, Simeon, Ira Lieberman, Joyita Mukherjee and Tatiana Nenova. 2002. 'Going Informal: Benefits and Costs.’ World Bank, Washington, DC.

Doner, Richard and Ben Ross Schneider, Business Associations and Economic Development: Why Some Associations Contribute More Than Others, Business and Politics, vol. 2. no. 3, 2000.

Engelschalk, Michael, Small Business Taxation in Transition Countries. 2005. World Bank, Washington DC.

Evans, Peter and James Rauch. 1999. Bureaucracy and Growth: A Cross-National Analysis of the Effects of 'Weberian' State Structures on Economic Growth, American Sociological Review 64: 748-765.

Farrell, Diana.2004. The Hidden Dangers of the Informal Economy, McKinsey Quarterly.

FIAS, June 2006. Survey Analysis Report of Sources of Informal Economic Activity in Sierra Leone.

Geertz, Clifford. 1963. Peddlers and Princes: Social Development and Economic Change in Two Indonesian Towns, University of Chicago Press.

Goldsmith, Arthur A., Business Associations and Better Governance in Africa, Public Administration and Development, 22, 2002.

Hanousek, Jan and Filip Palda. 2004. Quality of Government Services and the Civic Duty to Pay Taxes in the Czech and Slovak Republics, and other Transition Countries, Kyklos, vol 57(2).

Hart, Keith. 2005. Formal Bureaucracy and the Emergent Forms of the Informal Economy, UNU-Wider Research Paper No. 2005/11. Available at 
http://www.wider.unu.edu/publications/rps/rps2005/rp2005-11.pdf (accessed August 2006).

Hart, Keith. 2006. Informality: The Problem or the Solution? Paper Presented at the World Bank PSD Forum, Washington, DC April 4-6 ${ }^{\text {th }}$.

Jaffee, Steven et al., Food Safety and Agricultural Standards: Challenges and Opportunities for Developing Country Exports, Poverty Reduction and Economic Management Trade Unit and Agriculture and Rural Development Department, World Bank, January 2005.

Joshi, Anuradha and Joseph Ayee. 2002. Taxing for the State: Politics, Revenue and the Informal Sector in Ghana. IDS Bulletin, vol. 33 no. 3. 2002.

Kenyon, Thomas and Emerson Kapaz. 2005. The Informality Trap, Viewpoint Series, Note 301. World Bank Group, Private Sector Development Vice-Presidency, Washington, DC.

King, Kenneth. 1995. Jua Kali Kenya: Change \& Development in an Informal Economy, Ohio University Press.

King, Kenneth. 2001. Africa's Informal Economies: Thirty Years On, SAIS Review vol. XXI no. 1, Winter-Spring 2001.

Kurz, Sonia and Alena Frode. 2005. Promoting the Business and Investment Climate: Experiences of German Technical Assistance, Deutsche Gesellschaft fur Technische Zusammenarbeit (GTZ).

Locke, Richard M. 2006. 'Building Trust,' mimeo, Massachusetts Institute of Technology.

Lund, Francie and Caroline Skinner. 2005. Creating a Positive Business Environment for the Informal Economy: Reflections from South Africa. Paper prepared for the International Donor Conference 'Reforming the Business Environment'. Cairo, 29 November-1 December.

Malesky, Edmund. 2006. Entrepreneurs on the Periphery: A Study of Private Sector Development Beyond the High Performing Cities and Provinces of Vietnam. Available at www-irps.ucsd.edu/academics/Filesemalesky/Malesky_MPDF_periphery.online.pdf (accessed August 2006)

Maloney, William F. 2006. 'Deconstructing Informality: What Makes Informality Such a Bad Word?’ mimeo, World Bank. 
Organisation for Economic Cooperation and Development. 2004. Informal Employment and Promoting the Transition to a Salaried Economy, in OECD Employment Outlook 2004, Paris.

Palmade, Vincent, Industry Level Analysis: The Way to Identify the Binding Constraints to Economic Growth, World Bank Policy Research Working Paper No. 3551, March 2005.

Rogerson, Christian. 2004. Pro-Poor Local Economic Development in Post-Apartheid South Africa, The Johannesburg Fashion District, International Development Policy Review, 26(4).

Small Business Council. 2004. Informal Economy: Small Businesses in the Informal Economy: Making the Transition to the Formal Economy, available at http://www.sbs.gov.uk/SBS_Gov_files/sbc/informaleconomy.pdf (accessed July 2006)

Small Business Project. 2005. Counting the Cost of Red Tape for Business in South Africa: Regulatory Costs as a Burden for South Africa's Business, available at http://www.eldis.org/static/DOC19238.htm (accessed August 2006).

Taussig, Markus, Private Enterprise Formality and the Role of Local Government, Asian Development Bank Discussion Paper \#2, November 2004.

Tendler, Judith. 2002. Small Firms, the Informal Sector, and the Devil's Deal, IDS Bulletin, Vol. 33, No. 3, July 2002.

Tenguez, Alper and Rainer Klump. 2005. Strategies of the State towards the Informal Economy, available at http://www.wider.unu.edu/conference/conference-20053/conference-2005-3-papers/Teng\%FCz\%20\&\%20Klump.pdf (accessed July 2006)

USAID. 2005. Removing Barriers to Formalization: The Case for Reform and Emerging Best Practice, Washington DC.

Wahl, Martin and Ralf Meier. 2005. How a Business Membership Organization can Contribute to Improving the Business Environment in Northeast Brazil, Deutsche Gesellschaft fur Technische Zusammenarbeit (GTZ).

Wallace, Claire and Rossalina Latcheva. 2006. Economic Transformation Outside the Law: Corruption, Trust in Public Institutions and the Informal Economy in Transition Countries of Central and Eastern Europe. Europe-Asia Studies, vol. 58(1).

Winterberg, Susan J., Still on the Other Path? The Impacts of Business Formalization in Peru and their Lessons for SME Development Policy, available at http://web.mit.edu/sigus/www/NEW/Peru_Website/SIGUS/linked\%20files/WinterbergSIGUSPeruPaper.pdf (accessed August 2006). 
